\title{
Factor VII Deficiency
}

National Cancer Institute

\section{Source}

National Cancer Institute. Factor VII Deficiency. NCI Thesaurus. Code C131631.

A coagulation disorder characterized by the partial or complete absence of factor VII activity in the blood. 